\title{
ВПРОВАДЖЕННЯ ІНСТРУМЕНТІВ ПРОЕКТНОГО ПІДХОДУ В СИСТЕМУ ПУБЛІЧНОГО УПРАВЛІННЯ
}

\author{
Харченко Тетяна Олександрівна \\ кандидат економічних наук \\ Сумський національний аграрний університет (м.Суми, Україна) \\ ORCID: 0000-0002-3446-6533 \\ tetyana_22_82@ukr.net \\ Самойленко Тетяна Григорівна \\ Сумський національний аграрний університет (м.Суми, Україна) \\ ORCID: 0000-0002-1780-8693 \\ tasam101115@gmail.com
}

Проблеми переходу до проектно - орієнтованого управління за цільовими результатами національних проектів і державних програм дуже різнопланові і неоднозначні. Незважаючи на всі принципові відмінності в основах діяльності між бізнесом та державними органами, проектне управління як форма організації роботи може бути застосована і в роботі органів влади. Відсутність в рамках державних і місцевих цільових програм і підпрограм такого елемента, як проект з конкретним кінцевим продуктом, чіткими термінами і передбаченим фінансуванням, розмиває суть цих програм, нерідко зводячи їх до реалізації так званих "заходів", доцільність яких неочевидна. Актуальним є питання впровадження проектного управління в органах місиевого самоврядування, де реальний результат роботи оиінюється не тільки вищими інстанціями і контролюючими органами, а й безпосередньо жителями територій.

Ключові слова: проектний підхід, публічне управління, державне управління, публічне адміністрування, управління проектами.

DOI: https://doi.org/10.32845/bsnau.2019.1.4

Постановка проблеми в загальному вигляді. Поглиблення інтеграційних процесів України з країнами Європейського Союзу та розширенням напрямів міжнародної співпраці зумовило необхідність проведення структурних змін в тому числі і в системі державного управління. Ключовим вектором сучасних трансформацій в системі управління є побудова нових відносин між владою та суспільством, що обумовлено активно діючими процесами розширення публічності влади, й для досягнення результативності потребує впровадження нових якісних інструментів управління, як в органах державної влади, так і в органах місцевого самоврядування повноваження яких значно розширились. При цьому саме досягнення динаміки ефективності управлінських дій $€$ одним із вагомих фракторів формування нових моделей в системі державного управління з позиції публічного управління в умовах діючих децентралізаційних змін.

Обираючи коло найбільших ефрективних інструментів, котрі можуть бути впроваджені в систему публічного управління в України, доцільно враховувати сутнісні відмінності понять «державне управління», «публічне адміністрування» та «публічне управління», адже саме публічне управління розширює можливості взаємодії суспільства та влади з урахуванням позиції громадськості. При цьому варто зазначити, що в правовому полі, найбільш врегульованим та обгрунтованими $€$ відносини, котрі виникають в системі державного управління. Саме тому актуальними та потребуючими подальшого дослідження $€$ питання формування ефективної системи публічного управління та пошуку найбільш адаптованих інструментів для досягнення динаміки якості управління.

Аналіз останніх досліджень і публікацій. Дослідження питань пов'язаних з системою публічного управління мають багаторічну практику та широкий ареал досліджень, як зарубіжної, так і вітчизняної наукової спільноти. У складі за-

рубіжних науковців доцільно відмітити наукові здобутки Вебера М., Вільсона В., Осборна Д., Саймона Г., Турена А., Файоля А., Фельдмана Д., Худа К. У вітчизняному науковому полі вагомий внесок в розвиток науки публічне управління зроблено такими науковцями, як Авер'янов В., Андрійко О., Атаманчук Г., Бакуменко В., Білинська М., Бодров В., Ковбасюк Ю., Колодій А., Коломоєць Т., Мартиненко В., Оболенський О., Пасічник М.,Радченко О., І. Розпутенко І., Трощинський В., Шаров Ю. та іншими.

Загальновизнано, що процес управління $є$ мультифункціональним, як за об'єктом, так і за предметом дослідження та охоплює всі сфери діяльності суспільства в тому числі і сферу державного управління. Проте, не зважаючи на наявність значною кількості публікацій, питання формування ефективної системи публічного управління в Україні потребує подальшого дослідження, адже й зараз вона знаходиться на етапі становлення. Також варто зазначити, що на сьогодні, існує низка суперечливих тверджень щодо сутнісного наповнення дефініції «публічне управління», яка тісно корелює 3 поняттями «публічне адміністрування» та «державне управління», що вказує на необхідність поглиблення досліджень в даному наукові полі.

Формулювання цілей статті. Дослідження сутності категорії «публічне управління», визначення ключових елементів системи публічного управління в України та дослідження напрямів підвищення ефективності публічного управління за рахунок впровадження інструментів проектного підходу.

Методи дослідження. В процесі дослідження були використані методи системного аналізу, а також методи порівняльного, структурного, функціонального аналізу. 3 метою дослідження та узагальнення поглядів вчених щодо теорії та методології проектного управління в державному управлінні застосовувалися методи аналізу і синтезу. 
Виклад основного матеріалу дослідження. В межах науки публічне управління існує низька підходів щодо змістовного наповнення категорій «державне управління», «публічне адміністрування» та «публічне управління». При цьому за деякими відбувається ототожнення зазначених категорій, за деякими досліджується трансформація від категорії «державне управління» до категорії «публічне управління», за деякими всі категорії розглядаються в окремих проекціях. Досліджуючи дане питання Михайловська О., Філіпова Н. та інші автори (Михайловська О., Філіпова Н. та інш, 2016) зазначають, що наявність ототожнення зазначених категорійних понять обумовлена тим, що в їх основі лежать терміни «управління» та «менеджмент», які при перекладі з англійської мови вітчизняними науковцями інтерпретуються по-різному. При цьому категорія «державне управління» $€$ широко вживаною, як науковцями, так і практиками ще з часу командно-адміністративного устрою, в той же час категорії «публічне адміністрування» та «публічне управління» $є$ більш новими та залученими із термінології зарубіжних країн (Михайловська О. В., 2016). Для визначення ключових елементів системи публічного управління проаналізуємо її становлення в науковому середовищі. Розглядаючи питання співвідношення державного управління та публічного адміністрування Колесникова К. зазначає, що категорія «публічне адміністрування» $€$ перехідною ланкою між категорією «державне управління» та «публічне управління» (Колесникова К. О., 2013). При цьому Міненко М. вважає, що саме зміна бюрократичної моделі державного сектора на ринкову зумовило необхідність переходу від категорії «державного управління» до категорії «публічне адміністрування», а згодом трансформувалось у публічне управління (Міненко М.А., 2013). Що стосується змістовного наповнення категорії «державне управління», детальний аналіз дефініцій якої проведено Михайловською О., Філіповою Н. та іншими авторами, в їх основі лежить класичне визначення управління в державному секторі наведене Вебером М. (Михайловська О. В.,2016). Підсумовуючи зупинимось на твердженні Філіової Н., яка розглядає державне управління як окремий виду державної діяльності, котрий являє собою систему елементів державної влади та функціонує в якості регулятора між сфрерами державної діяльності (Філіпова Н. В., 2015). Переходячи до категорії «публічне адміністрування», варто відмітити, що її як правило розглядають з позиції адміністрування в якості організаційнорозпорядчого методу. Так, в енциклопедії державного управління, публічне адміністрування $€$ одним із видів управлінської діяльності публічної влади, в рамках якої управління взаємодією держави та громадського суспільства забезпечує подальший розвиток держави у визначеному напрямку (Філіпова Н. В., 2015).

Враховуючи сучасні тенденції рефрормування системи державного управління в частині поглиблення публічності влади розглянемо сутність категорії «публічне управління», які були запропоновані Оболенським Ю. та Мельником А., як двоскладової системи, де одною складовою виступає державне управління, а іншою - громадське управління, суб'єктами яких $є$ відповідно органи державної влади та громадські інституції. Отже, виходячи з даного твердження, ключовими елементами системи публічного управління $є$ органи державної влади, громадянське суспільство та недержавні організації (Міненко М. А., 2014, Оболенський О. Ю., 2013). Також ватро навести й характеристику «публічного управління», котра була наведена в перше Кілінгом Д., як визначення кращого способу використання ресурсів для забезпечення реалізації пріоритетів державної політики (Keeling, D.,1972). Слід відмітити, що дане твердження тісно корелює з сутністю проектного підходу, адже його головним завданням є досягнення визначеної мети в умовах обмеженості ресурсів та часу. Підсумовуючи зазначимо, що державне управління характеризується чіткою координацією дій згори до низу суб'єктом управління, при цьому в публічному управлінні вплив суспільства на визначення ключових пріоритетів розвитку $є$ значно вагомішим, що підтверджується і ст. 5 Конституції України, де саме народу визначено ключову функцію здійснення влади в тому числі й через органи державної та місцевої влади (9).

Хоча можливості впливу суспільства на реалізацію державної політики в умовах децентралізації значно розширились, проте залишається низка проблемних питань пов'язаних саме з процесом управління. Постійні трансформації українського суспільства, обмеженість ресурсів та часу, альтернативність вибору, розширення векторів міжнародної співпраці тощо посилюють вимоги до представників управлінської ланки в частині прийняття ефективних управлінських рішень. Одним із проблемних питань пов'язаних з розширення можливостей розвитку суспільства $€$ неефективність діяльності регіональних та місцевих органів управління. Дана тенденція сформувалась під впливом розширення повноважень органів місцевого самоврядування на містах та відсутності належних управлінських здібностей у більшості представників місцевої влади. Наразі дане питання є проблемним в цілому для України, адже в межах діючої протягом багатьох років системи державного управління функція представників місцевих та регіональних органів управління обмежувалась виконання визначених «згори» завдань, що призвело до неспроможності більшості представників управлінської ланки приймати ефективні управлінські рішення для забезпечення результативність їх виконання. Отже одним із аспектів досягнення динаміки результативності діяльності органів місцевого самоврядування в умовах зміни підходів в системі публічного управління $€$ досягнення ефективності прийнятих управлінських рішень та визначення напрямів оцінки їх впровадження в певних ключових точках. Крім того важливим $€$ обґрунтування стратегій розвитку громад в основу яких будуть покладені перспективні напрями розвитку з визначенням конкретних цілей та проектів, реалізація яких забезпечить їх досягнення.

На сучасному етапі розвитку Україна обрала стратегію переходу до публічного типу державного управління. Одним з найважливіших напрямків реалізації даної стратегії $€$ модернізація системи державного управління за допомогою підвищення ефективності діючих державних програм (проектів). Але вирішення завдання модернізації системи публічного управління неможливе за допомогою лише бюрократичних методів. Адже існуюча на сьогодні сукупність діючих державних програм в переважній більшості є малоефективною, саме тому широкого використання набуває практика інтеграції в систему державного управління методів проектного підходу. Даний факт визначає необхідність створення чіткого та адекватного інструментарію управління державними проектами на базі трансферту та адаптації управлінських підходів, які активно використовуються бізнес-структурами. Для поширення технологій менеджменту, які неодноразово довели 
свою ефективність в бізнес-середовищі, а також з метою розвитку публічного управління в Україні, доцільно розвивати державно-приватне партнерство у формі аутсорсингу частини державних функцій у виконанні проекту.

Слід зазначити, що проектний підхід історично пов'язаний і зобов'язаний своїм походженням саме державним програмам (проектам), що дає підстави розглядати його як методологічну основу, найбільш адаптовану для модернізації системи державного управління. В основі проектного підходу, котрий дасть змогу збільшити ефективність діючих державних програм (проектів) та уникнути помилок при розробці нових, покладено принципи актуальності, здійсненності та сталості проекту.

Проектний підхід являє собою метод використання процесного підходу для аналізу та управління унікальними процесами - проектами. Проектний підхід успадковує всі принципи і властивості системного і процесного підходів. Проект це унікальний процес, що складається із сукупності скоординованої і керованої діяльності з датами початку та закінчення, розпочатий для досягнення мети, яка відповідає конкретним вимогам, що включає обмеження термінів, вартості та ресурсів.

Систематизація робіт з проектного управління дозволяє виділити два основних історично сформованих на суч асному етапі напрямки теорії управління проектами:

- математичні і графрічні методи управління проектом, включаючи інформаційні системи підтримки управління проектами;

- інституційно-методологічні основи управління проектами.

Перевагою проектного підходу саме в системі публічного управління $є$ його інтегрованість, що передбачає узгодженість цілей (національних, секторальних, регіональних, місцевих) та побудови логічних структур проектів (програм), що дасть змогу визначити контрольні точки реалізації проекту та внести корективи в разі відхилення від плану реалізації. Формування напрямів розвитку із застосуванням проектного підходу дозволить визначити сукупність проектів за кожним напрямом, реалізація яких дозволить досягти визначеної мети. Кожен проект буде містити розроблений план робіт з ресурсами і видатками у розрізі результатів та організаційну структуру виконавців проекту, що дасть змогу зменшити ризик не виконання через некоректно побудовану систему управління та визначення відповідальних осіб. Постійний моніторинг та оцінка результативності виконання в ключових точках, що досягається шляхом об`єднання і координації всіх інформаційних систем проекту в єдину систему та наявності зв 'язку усіх складових розробки і втілення проекту з системою управління персоналом забезпечить результативність управління проектом. Варто зазначити, що саме інтегрованість проектного підходу забезпечує функціонування проекту як цілісного механізму взаємозалежних процесів: програмування, ідентифікації, формулювання, фінансування, впровадження, оцінки та аудиту.

Також одним із інструментів проектного управління $є$ логіко-структурний підхід, котрий складається 3 аналізу та планування, при цьому до фрази аналізу включають аналіз учасників, проблеми, цілей та стратегії; фаза планування включає логічну структуризацію проекту, планування діяльності та ресурсів, що у підсумку дає змогу побудувати логіко- структурну матрицю проекту. Погоджуючись з думкою Чемерис А., зазначимо, що перевагою даного підходу в інструментарії управління проектами є можливість його застосування на всіх етапах реалізації проекту наступним чином:

- на етапі ідентисікації застосовується для проведення аналізу дійсної ситуації, визначення актуальності запропонованого проекту, а також його потенційних цілей і стратегій;

- на етапі формулювання допомагає у підготовці відповідного плану проекту з чітко визначеними цілями, вимірними результатами, стратегією управління ризиками і встановленими рівнями управлінських зобов'язань;

- на етапі виконання проекту/програми є основним управлінським інструментом для укладання контрактів, складання операційних планів і моніторингу робіт;

- на етапі оцінки й аудиту представляє собою зведений звіт того, що планувалось (цілі, індикатори й основні припущення), i, таким чином, служить основою для оцінки діяльності й впливу (Чемерис А.,2012).

Актуальність вдосконалення публічного управління в даний час обумовлена вичерпністю і досить низькою ефективністю традиційних форм державного управління, заснованих на жорсткому адмініструванні, суворій ієрархії і централізації. Тенденції розвитку сучасного суспільства відображають необхідність формування нових підходів до організації та реалізації публічного управління, що підтверджується реорганізацією органів влади, вдосконаленням нормативно-правової бази для підвищення ефективності їх діяльності, розширенням переліку публічних послуг, інтеграцією нових інформаційних технологій і управлінських структур.

Теоретичною основою для цілого комплексу напрямків по модернізації системи державного управління в Україні $€$ теорія «нового публічного управління» (New Public Management), невід'ємними елементами якої виступають маркетінізація та клієнтоорієнтованість, ефективність і відповідальність за результати діяльності держави, доповнена принципом рівноправних партнерський відносин держави і суспільства і використання інформаційних технологій концепції «е-Governance».

Можливості проектного управління при реалізації державних (програм) проектів електронного уряду:

1. Необхідність забезпечення прозорості процедур та можливість оперативного надання звітів про хід етапів, витраті бюджетних ресурсів та якісь результатів проекту

2. Клієнтоорієнтованість. Мета - задоволення потреб населення. Інструменти планування, забезпечення і контролю якості проекту, наприклад, сім інструментів «7QC»

3. Розробка та впровадження інновацій, які пов'язані з новизною і нерегулярністю, невизначеністю. Проект являє собою тимчасове підприємство, якому характерна певна новизна і унікальність результатів. Універсальні набори прийомів і стандарти управління проектами надають основу для будьякого нового проекту.

4. Підпорядкованість життєвого циклу інновації електронного уряду. Концепція управління стадіями проекту: ініціації, планування, виконання, моніторингу та контролю, закриття

5. Прагнення державних службовців уникати ризиків. Інструменти управління ризиками проекту: ієрархічна структура ризиків (RBS); матриця ймовірності і впливу; діаграми впливу; SWOT-аналіз ризиків; стратегії реагування на ризики

Вісник Сумського національного аграрного університету

Серія «Економіка і менеджмент», випуск 1 (79), 2019 
з позитивним і негативним впливом та ін.

6. Потреба в вузькоспеціалізованих професіоналах Створення матричних структур, внутрішніх міжфункціональних і зовнішніх державно-приватного проектних офісів. Управління командою проекту.

7. Велика кількість груп зацікавлених сторін проекту. Аналітичні методи управління зацікавленими сторонами проекту: матриця влади / інтересів, матриця влади; матриця впливу / впливу; модель особливостей та ін. Програмне забезпечення управління інформацією і комунікаціями проекту.

8. Заздалегідь певний бюджет і тимчасові обмеження проекту, «спускаються» зверху Інструменти управління вартістю: оцінка за трьома точкам; управління освоєним обсягом (EVM); аналіз резервів; аналіз відхилень і ін.

9. Потреба у великій кількості різноманітних видів ресурсів

Висновки 3 проведеного дослідження і перспективи подальших розвідок. Підсумки проведеного аналізу стану системи державного управління дозволяють виділити напрямки, що визначають перспективи розвитку і практичного впровадження проектного управління в органах влади:
- активна діяльність основних інститутів розвитку проектного управління в органах влади по розширенню відповідної методологічної та нормативно-правової бази;

- проектне управління повинно стати невід'ємним елементом реалізації стратегічних цілей держави;

- залучення до управління державними проектами професіоналів проектного управління в індивідуальному порядку в якості консультантів, а також на основі створення спільних державно-приватних проектних офісів;

- повсюдне навчання державних службовців сучасним методам проектного управління та організації сертифікації за спеціально розробленим стандарту проектного управління;

- мотивування державних службовців та посадових осіб до участі в роботі проектних офісів і до використання технологій проектного управління, в тому числі на основі включення цих критеріїв в систему оцінки їх діяльності;

- створення і поширення уніфікованого, гнучкого і доступного програмного забезпечення підтримки проектної діяльності в органах влади.

\section{References:}

1. Keeling, D. Management in Government [Text] / D. Keeling. - London: Allen \& Unwin, 1972. - 216 p. https://doi.org/10.4324/9780203701690

2. Entsyklopediia derzhavnoho upravlinnia: u 8 tomakh / Nats. akad. derzh. upr. pry Prezydentovi Ukrainy; nauk.-red. kolehiia: Yu. V. Kovbasiuk (holova) ta in. - K.: NADU, 2011.: T. 8: Publichne vriaduvannia / nauk.red.kolehiia: V. S. Zahorskyi (holova), S.O. Teleshun (spivholova) ta in. - Lvivskyi rehionalnyi instytut derzhavnoho upravlinnia Natsionalnoi akademii derzhavnoho upravlinnia pry Prezydentovi Ukrainy. - Lviv : LRIDU NADU, 2011, pp.630.

3. Kolesnykova K. O. (2013). Spivvidnoshennia derzhavnoho upravlinnia ta publichnoho administruvannia u protsesi suspilnoi transformatsii [The relationship between public administration and public administration in the process of social transformation]. Publichne upravlinnia: teoriia ta praktyka [Public administration: theory and practice]. no.3, pp.41-45.- Available at:: http://nbuv.gov.ua/UJRN/Pubupr_2013_3_8. (Accessed 14.08.2019)

4. Konstytutsiia Ukrainy vid 28.06.1996 r. № 254k/96-VR [Tekst] // Vidomosti Verkhovnoi Rady Ukrainy. - 1996. no.30.

5. Mykhailovska O. V., Filipova, L. S Ladonko, N. V. Tkalenko (2016). Analiz teoretychnykh pidkhodiv do vyznachennia sutnosti skladovykh definitsii publichnoho upravlinnia ta administruvannia [Analysis of theoretical approaches to defining the essence of the definitions of public administration and administration]. Universytetski naukovi zapysky [Notes of University of Sciences].no 2 , pp.241-253. - Available at:: http://nbuv.gov.ua/UJRN/Unzap_2016_2_24. (Accessed 14.08.2019)

6. Minenko M.A. (2013). Transformatsiia systemy derzhavnoho upravlinnia v suchasni mdeli rehuliuvannia suspilstva [Transformation of public administration into modern models of regulation of society]. Derzhavne upravlinnia: udoskonalennia ta rozvytok [Public Administration: Improvement and Development]. (electronic journal), no.6 Available at:: http://www.dy.nayka.com.ua/?op=1\&z=581 (Accessed 16.08.2019)

7. Minenko M. A. (2014). Publichne upravlinnia: teoriia ta metodolohiia [Public administration: theory and methodology] [Tekst] : monohrafiia-K. : Kyiv. nats. torh.-ekon. un-t, pp.404 .

8. Obolenskyi O. Yu. (2013). Rozvytok suspilstva ta publichne upravlinnia [Community Development and Public Management]. Visnyk Natsionalnoi akademii derzhavnoho upravlinnia pry Prezydentovi Ukrainy [Bulletin of the National Academy of Public Administration under the President of Ukraine]. no. 3.pp 27-33.

9. Filipova N. V. (2015). Zmina spivvidnoshennia poniat "derzhavne upravlinnia", "publichne administruvannia", "publichne upravlinnia" v systemi suspilno-politychnoi transformatsii [Changing the relation between the concepts of "public administration", "public administration", "public administration" in the system of socio-political transformation] Derzhavne upravlinnia: udoskonalennia ta rozvytok [Public Administration: Improvement and Development] (electronic journal), no.6. - Available at: http://nbuv.gov.ua/UJRN/Duur_2015_6_5. (Accessed 18.08.2019)

10. Chemerys A. (2012). Rozroblennia ta upravlinnia proektamy u publichnii sferi: yevropeiskyi vymir dlia Ukrainy. Praktychnyi posibnyk [Public project development and management: a European dimension for Ukraine]. Shveitsarsko-ukrainskyi proekt «Pidtrymka detsentralizatsii v Ukraini - DESPRO». - K. : TOV «Sofiia-A», pp. 80

Tetyana Kharchenko, PhD, Sumy National Agrarian University (Sumy, Ukraine)

Tetiana Samoilenko, Sumy National Agrarian University (Sumy, Ukraine)

Implementation of the project approach tools in the public governance system

At the present stage of development of Ukraine has chosen the strategy of transition to the public type of public administration. One of the major directions of implementation of this strategy is the modernisation of the public administration system through the 
implementation of state programs (projects).

The problems of transition to project - oriented management for the intended results of national projects and state programs in a very diverse and ambiguous. Despite fundamental differences in the basis of activities between business and state authorities, project management as a form of work organization can be applied in the work of the authorities. The absence under the state and local target programs and subprograms of the element of the project with a specific end product, a clear timeline and provided the financing, blurs the essence of these programs, often reducing them to implement the so-called "measures", the feasibility of which is not obvious. Urgent issue of the implementation of project management in local government, where the real result of the work is evaluated not only by the highest authorities and regulatory agencies, but also directly to the inhabitants of the territories.

Although the possibility of influence of society on the implementation of state policy in conditions of decentralization has expanded, however there remain a number of problematic issues associated with the management process. Permanent transformation of the Ukrainian society, the limited resources and time, alternativeness of a choice, the expansion of the vectors of international cooperation and the like are tightening requirements for managers in taking effective management decisions. one aspect of achieving the dynamics of the performance of local authorities in the context of changing approaches to public management is achieving the effectiveness of management decisions and identify areas for assessment of their implementation in certain key points. Also important is the justification of strategy of development of society which will be based on perspective directions of development of concrete goals and projects that will ensure their achievement.

Key words: project approach, public administration, state administration, public authorities, project management.

Дата надходження до редакції: 03.12.2018 p. 